\title{
Efficacy of varroacidal food additive appliance during summer treatment of honeybee colonies (Apis mellifera)
}

\author{
Ivana Tlak Gajger ${ }^{1 *}$, Petar Sušec ${ }^{2}$ \\ ${ }^{\prime}$ Department for Biology and Pathology of Fish and Bees, Faculty of Veterinary Medicine, University of \\ Zagreb, Zagreb, Croatia \\ ${ }^{2}$ Faculty of Veterinary Medicine, University of Zagreb, Zagreb, Croatia, student
}

\section{TLAK GAJGER, I., P. SUŠEC: Efficacy of varroacidal food additive appliance during summer treatment of honeybee colonies (Apis mellifera). Vet. arhiv 89, 87-96, 2019.}

\begin{abstract}
The aim of this field study was to evaluate the varroacidal efficacy of the product Hive Clean ${ }^{\circledR}$ during summer treatment of honeybee colonies (Apis mellifera). Treatment efficacy was assessed by counting the number of Varroa destructor mites killed after multiple applications of Hive Clean ${ }^{\circledR}$, according to the instructions provided by the producer. Hive Clean ${ }^{\circledR}$ was applied consecutively, with two varroacides with different active ingredients as shock treatment. The treatment with Hive Clean ${ }^{\circledR}$ resulted in a median mite drop of $91.51 \%$ (89.25-93.26\%). Total mite mortality was always significantly higher than the natural mite fall observed during the pre-treatment period. According to the results obtained, Hive Clean ${ }^{\circledR}$, as a food additive with acaricidal effect, could be considered an appropriate alternative for varroosis control and also suitable for use in combination with authorized veterinary medicine products, in organic and conventional apiaries under mild climate conditions.
\end{abstract}

Key words: Apis mellifera; Varroa destructor; Hive Clean ${ }^{\circledR}$; varroacidal efficacy

\section{Introduction}

Pathogens, pests and other adverse environmental factors, whether individually or simultaneously, have been implicated in high annual losses of honeybee colonies (Apis mellifera) (GOULSON et al., 2015). Potentially, the major contributing factor in the dissipated health of honeybee colonies is the obligate ectoparasitic mite Varroa destructor (MARTIN et al., 2012; NAZZI et al., 2012; ZIEGELMANN et al., 2013). As the $V$. destructor mite feeds on the haemolymph of adults and developing stages of bees, while also facilitating the transmission of certain viruses (CHEN et al., 2004; DI PRISCO et al., 2011; RYABOV et al., 2014; NAZZI and

\footnotetext{
*Corresponding author:

Ivana Tlak Gajger, PhD, DVM, Department for Biology and Pathology of Fish and Bees, Faculty of Veterinary Medicine, University of Zagreb, Heinzelova 55, 10000 Zagreb, Croatia, Phone: +385 12390 151; Fax: +385 12390 211; E-mail: ivana. tlak@vef.hr 
I. Tlak Gajger and P. Sušec: Efficacy of varroacidal food additive appliance during summer treatment of honeybee colonies

LE CONTE, 2016), this seems to have a significant negative effect on the host immune response (YANG and COX-FOSTER, 2005). New research shows that this parasite damages host adult bees by consuming their fat body (RAMSEY et al., 2018). The $V$. destructor mite population in honeybee colonies requires regular control, as the high rate of parasitic mites and poor colony management leads to its collapse.

There are numerous active ingredients available incorporated into different formulations and authorized as veterinary medicinal products (VMP) for use in beekeeping, including a range of acaricidal substances, different methods of application, and techniques for combating $V$. destructor mites. A variety of synthetic acaricides have been widely used in recent decades with variable effects, often in response to poor beekeeping practices, such as: multiple consecutive and repeated use of the same product, improper time and manner of varroacidal product application, sub- or over dosage, too short or too long treatment time, too few active ingredients in the same treatment, etc., which has led to increased tolerance to most of them. Since $V$. destructor mites have developed resistance to the most widely used synthetic active ingredients of acaricides (SAMMATARO et al., 2005; MAGGI et al., 2010), and in order to avoid the accumulation of chemicals residues in hive products (LODESANI et al. 2008; MULLIN et al. 2010), beekeepers are extremely interested in alternative treatments with substances of natural origin with varroacidal effects (i.e. soft acaracides), such as organic acids, plant extracts, essential oils and their components (GOSWAMI et al., 2014; RUFFINENGO et al., 2014; STANIMIROVIĆ et al., 2017; TLAK GAJGER et al., 2013). Eco friendly, natural products have certain advantages after repeated use, such as the lower risk of honey and beeswax contamination, or the small possibility of inducing $V$. destructor mite resistance. However, their efficacy may be inconsistent and more variable compared to synthetic acaricide formulations (ROSENKRANZ et al., 2010).

Hive Clean ${ }^{\circledR}$ is a natural mite control product, distributed and marketed as a food additive for honeybee colonies. According to the product label, it is a mixture of oxalic, formic and citric acids, extracts of propolis, essential oils, sucrose and water. Research has been conducted on the efficacy of this varroacidal product for controlling mites during autumn treatments (AKYOL and YENINAR, 2008; HOWIS and NOWAKOVSKI, 2009). The objective of this study was to evaluate and compare the varroacidal efficacy and mite mortality dynamic during summer treatment of honeybee colonies with Hive Clean ${ }^{\circledR}$, when used consecutively with shock treatment using an authorized VMP for varroosis control (coumaphos, CheckMite+ ${ }^{\mathbb{R}}$ ). Additionally, the commonly used amitraz $\left(\right.$ Varidol $^{\mathbb{B}}$ ) was used for winter treatment in broodless honeybee colonies where it was believed to establish the final parasitic mite drop.

\section{Materials and methods}

Location and field trial design. The test apiary was located in the continental part of Croatia $\left(45^{\circ} 55^{\prime} 36^{\prime \prime} \mathrm{N}, 16^{\circ} 32^{\prime} 42^{\prime \prime} \mathrm{E}\right)$ which has a mild climate. The field experiment was conducted on thirty honeybee colonies (A. mellifera) populated in a standard Langsthrot Root (LR) hive type containing ten combs in each brood and honey compartments. Prior to the experimental period all colonies were equalized in respect to brood size, the comb area coverage with adult bees and the amount of stored honey and pollen (DELAPLANE et al., 2013). During equalization, all honeybee colonies were visually inspected for adult bees and brood pathology, and then were divided into 
I. Tlak Gajger and P. Sušec: Efficacy of varroacidal food additive appliance during summer treatment of honeybee colonies

three experimental groups (A, B, C), each of 10 hives (Table 1). In early June, metal sheets with oily paper were placed on the floor of each test hive in order to record the natural mite mortality prior to treatment (30 days, from June 1 to June 30). Above the sheets wire screens were installed to prevent contact of the bees with debris, and to prevent ants from removing dead mites.

Table 1. Field treatments design

\begin{tabular}{|c|c|c|c|c|c|c|}
\hline \multirow{2}{*}{$\begin{array}{l}\text { Experimental } \\
\text { group }\end{array}$} & \multicolumn{6}{|c|}{ Term of honeybee colonies treatments } \\
\hline & 1.6.-30.6. & 2.7 . & 9.7 . & 16.7. & 1.8.-14.9. & 01.12 . \\
\hline $\mathrm{A}$ & \multirow{3}{*}{$\begin{array}{l}V . \text { destructor mite mortality } \\
\text { prior to treatment }\end{array}$} & \multicolumn{3}{|c|}{ Hive Clean formulation } & & Amitraz \\
\hline $\mathrm{B}$ & & \multicolumn{3}{|c|}{ Hive Clean formulation } & Coumaphos & Amitraz \\
\hline $\mathrm{C}$ & & \multicolumn{3}{|c|}{ Coumaphos } & & Amitraz \\
\hline
\end{tabular}

Drugs and treatments. Treatments were conducted during the summer season, immediately after the main pasture honey harvesting, as follows: in groups A and B, the recommended dose of one plastic stick of $15 \mathrm{~mL}$ of Hive Clean ${ }^{\circledR}$ (BeeVital, Food \& Beverage Handels GesmbH, Seeham, Austria) was sprinkled between the frames, on the bees, three times at 7 day intervals (T1 - first application on day 1, T2 - second application on day 8, T3 - third application on day 15). In group $\mathrm{C}$, Check Mite ${ }^{\circledR}{ }^{\circledR}$ (Bayer, Germany) was applied, i.e. two beehive pest control strips were inserted between frames with combs in the brood chamber for a 45 day period. The August followup treatment with Check Mite $+{ }^{\circledR}$ was applied in group B only as described above. In the winter treatment period, Varidol ${ }^{\circledR}$ (TolnAgro, Hungary) was used once in all three experimental groups $(\mathrm{A}, \mathrm{B}, \mathrm{C})$ by fumigation, to determine the residual amount of mites. The treatment conditions are presented in Table 1.

Table 2. Calculations of treatment efficacy for acaricides applied on V. destructor infesting honeybee colonies

\begin{tabular}{|l|l|c|c|c|c|c|}
\hline \multirow{2}{*}{$\begin{array}{l}\text { Experimental } \\
\text { group }\end{array}$} & & \multicolumn{5}{|c|}{$\%$ in total $V$. destructor mite fall } \\
\cline { 3 - 7 } & Treatment type & Median & Min. & Max. & Lower quartile & Upper quartile \\
\hline $\begin{array}{l}\text { A } \\
(\mathrm{n}=10)\end{array}$ & Hive Clean $^{\circledR}$ & 91.51 & 89.25 & 93.26 & 90.71 & 93.26 \\
\cline { 2 - 7 } & Varidol $^{\circledR}$ & 8.49 & 6.74 & 10.75 & 7.96 & 10.75 \\
\hline \multirow{3}{*}{$\begin{array}{l}\mathrm{B} \\
(\mathrm{n}=10)\end{array}$} & Hive Clean $^{\circledR}$ & 88.75 & 84.32 & 91.46 & 87.07 & 91.46 \\
\cline { 2 - 7 } & ${\text { CheckMite }+{ }^{\circledR}}$ & 9.56 & 7.18 & 13.31 & 7.91 & 11.03 \\
\cline { 2 - 7 } & Varidol $^{\circledR}$ & 1.69 & 0.66 & 2.93 & 1.38 & 2.34 \\
\hline $\begin{array}{l}\mathrm{C} \\
(\mathrm{n}=10)\end{array}$ & ${\text { CheckMite }+{ }^{\circledR}}$ & 91.70 & 89.56 & 94.36 & 90.55 & 93.31 \\
\cline { 2 - 7 } & Varidol $^{\circledR}$ & 8.30 & 5.63 & 10.40 & 6.68 & 9.21 \\
\hline
\end{tabular}

During the treatment period, fallen mites stuck to the oily paper were sampled and transported to the laboratory every two days. After each sampling, the oily paper was replaced with a new sheet. Fallen $V$. destructor mites were counted in the pre-treatment and treatment periods, and the sum of those results, calculated after the final treatment, was considered the total mite drop. The proportion of mites falling after each treatment of the total fallen mites was estimated (\%). The 
I. Tlak Gajger and P. Sušec: Efficacy of varroacidal food additive appliance during summer treatment of honeybee colonies

percentages of mites killed by the experimental treatments for Group B were estimated according to the recommendations of the European Medicines Agency (ANONYM., 2008).

Statistical analysis. The data analyses were performed by ANOVA using the software package STATISTICA v. 13.3 (StatSoft, Inc, USA). The results were presented as the median, interval of variation and interquartile differences. Statistical differences between treatments were tested using the Mann-Whitney U and Kruskal-Wallis tests.

\section{Results}

During the treatment period, there were no reports of any toxic or other negative effects on the vitality of the adult honeybee population or brood development at the apiary level. During the 30 -day pre-treatment period, the average daily mite drop in the 30 honeybee colonies was 1.76 ( \pm $1.20)$, and these values did not differ significantly $(\mathrm{P}>0.05)$ between the experimental groups (Fig. 1). During the treatment period, the observed total mite mortality that resulted was significantly higher $(\mathrm{P}<0.0005, \mathrm{t}=5.663)$ than natural mite drop (Table 2).

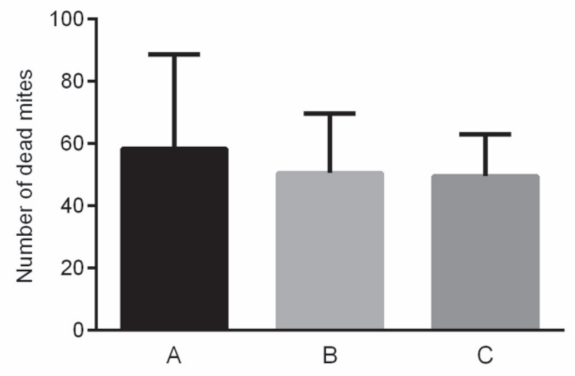

Fig. 1. Natural $V$. destructor mite drop in the pre-treatment period. Mean $\pm \mathrm{SD}$

In experimental group A, the treatment with Hive Clean ${ }^{\circledR}$ resulted in a median mite drop of $91.51 \%(89.25-93.26 \%)$ of the total mite mortality during the overall treatment period. The winter treatment with Varidol ${ }^{\circledR}$ in broodless honeybee colonies induced the fall of the remaining $8.49 \%$ parasitic mites $(6.74-10.75 \%)$. In experimental group B, the summer treatment with Hive Clean ${ }^{\circledR}$ resulted in a median mite drop of $88.75 \%(84.3-91.46 \%)$, while the shock treatment with CheckMite $+{ }^{\circledR}$ induced the death of $9.56 \%(7.18-3.31 \%)$ mites, and finally the winter treatment with Varidol $^{\circledR}$ caused the death of $1.69 \%(0.66-2.93 \%) V$. destructor mites. In experimental group C, the summer treatment with CheckMite $+{ }^{\circledR}$ caused median mite mortality of $91.70 \%$ (89.56-94.36\%), whilst the subsequent winter treatment of broodless colonies with Varidol ${ }^{\circledR}$ caused the death of the remaining $8.30 \%$ (5.63-10.40\%) $V$. destructor mites.

Mite mortality during the main summer treatment with Hive Clean ${ }^{\circledR}$ in experimental groups $A$ and $\mathrm{B}$ increased in the following order: $\mathrm{T} 1<\mathrm{T} 2<\mathrm{T} 3$, with the exception of hives 6 and 7 in group B (Fig. 2).

According to the results of the Mann-Whitney U test, the varroacidal efficacy of Hive Clean ${ }^{\circledR}$ during the summer treatment significantly $(\mathrm{P}<0.05, \mathrm{t}=3.173)$ differed between experimental groups A $(91.37 \pm 0.36)$ and B $(88.80 \pm 0.72)$ (Fig. 3). In experimental group B, the treatment efficacy of Hive Clean ${ }^{\circledR}$ was $88.75 \%$. 
I. Tlak Gajger and P. Sušec: Efficacy of varroacidal food additive appliance during summer treatment of honeybee colonies

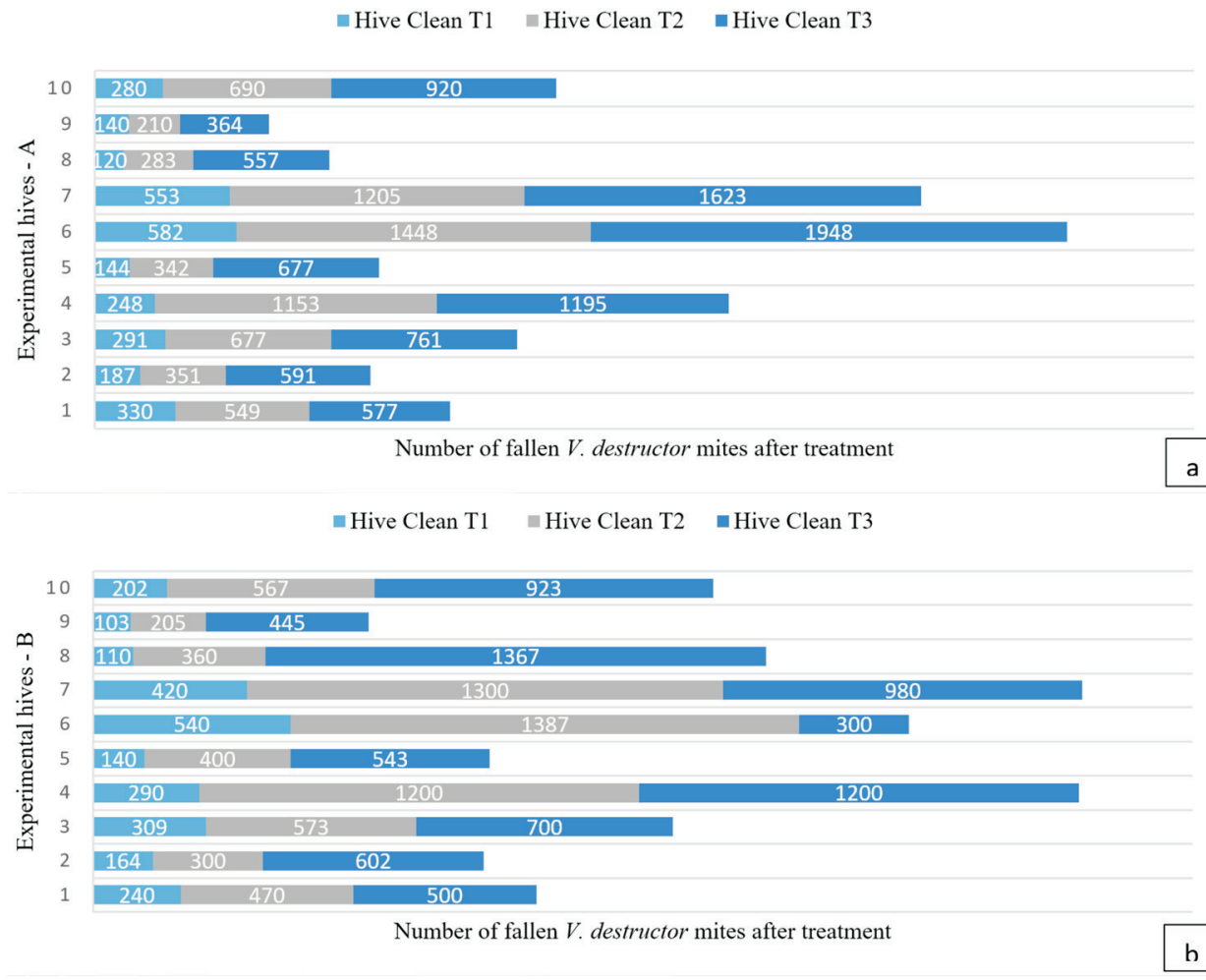

Fig. 2. a, b. V. destructor mite mortality during treatment of honeybee colonies (experimental hives A and B) with Hive Clean ${ }^{\circledR}$ (T1 - first application, T2 - second application, T3 - third application)

The results of Kruskal-Wallis test revealed that the efficiency of Varidol ${ }^{\circledR}$ between the three experimental groups was significantly different $(\mathrm{P}<0.0001, \mathrm{H}=19.52)$. The Mann-Whitney $\mathrm{U}$ test showed the significantly higher efficacy of Varidol $^{\circledR}$ in experimental group A compared to group $\mathrm{B}(\mathrm{P}<0.0005, \mathrm{t}=4.563)$, but the differences in the efficacy between experimental groups $\mathrm{A}$ and $\mathrm{C}$ were not significant $(\mathrm{P}>0.05)$. The efficacy of Varidol $^{\circledR}$ was also significantly different between experimental groups $\mathrm{B}$ and $\mathrm{C}(\mathrm{P}<0.0001, \mathrm{t}=11.488)$.

Treatment with CheckMite ${ }^{\circledR}$ in experimental group B induced a median drop of $9.56 \%$ mites, while in honeybee colonies from group $\mathrm{C}$, when applied as the first summer treatment, it caused a median mite drop of $91.70 \%$ (Fig. 3). There was a significant difference in the varroacidal effect $(\mathrm{P}<0.0001, \mathrm{t}=82.74)$ between groups $\mathrm{B}(9.51 \pm 1.95)$ and group $\mathrm{C}(91.93 \pm 1.64)$.

Vet. arhiv 89 (1), 87-96, 2019 
I. Tlak Gajger and P. Sušec: Efficacy of varroacidal food additive appliance during summer treatment of honeybee colonies
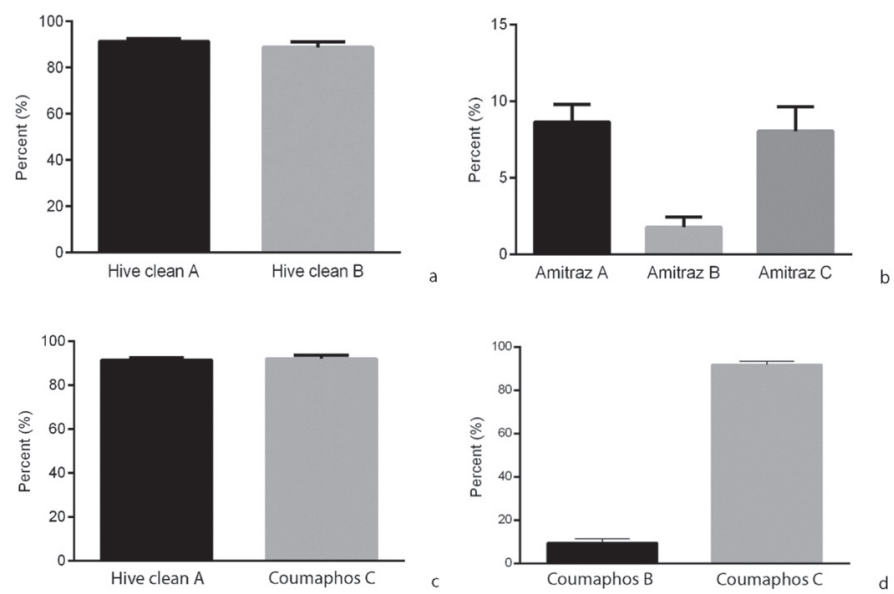

Fig. 3. a, b, c, d. Treatment efficacy of varroacides with different active ingredients a - Varroacidal efficacy (\%) of Hive Clean formulation in experimental groups A and B; b -Varroacidal efficacy (\%) of Amitraz during broodless treatment on residual mites in all experimental groups (A, B, C); c - Varroacidal efficacy (\%) of Hive Clean formulation in experimental group A and Coumaphos in experimental group C, $\mathrm{d}$ Efficacy (\%) of Coumaphos in experimental group B on residual mites after primary treatment with Hive Clean formulation and in experimental group $\mathrm{C}$ where it was applied as the first treatment. Mean $\pm \mathrm{SD}$

\section{Discussion}

According to the Varroa Control Program, which is part of the Croatian National Regulation on animal protection measures against infectious and parasitic diseases and on related financing (ANONYM., 2015; ANONYM., 2018), beekeepers nationwide are required to implement one obligatory treatment of honeybee colonies against $V$. destructor mites using an authorized VMP. Varroosis control is recommended in the period from $1^{\text {st }}$ July to $31^{\text {st }}$ August, with the schedule dependent on the geographical, climatic and pasture conditions in different regions.

Almost all available VMPs, as reflected in manufacturer's instructions, are most effective during the autumn treatments. Nevertheless, there are certain areas with main pastures and the last honey harvest from stationary apiaries in mid-June, and therefore honeybee colonies require treatment much earlier (during the summer) to prevent varroosis damage and to decrease the extent of the extra risk of winter losses.

Most authorized VMPs are acaricides, only present on the local market for periods of three or more active beekeeping seasons. Accordingly, beekeepers are aware of the risks of mite resistance development, and of contamination of beeswax and honey. Also, special requirements linked with mite control in ecological beekeeping are leading to the necessity for testing new product formulations and food additives with acaricidal efficiency to improve $V$. destructor mite infestation techniques. Hive Clean ${ }^{\circledR}$ is an entirely organic natural mite control product and, as such, is suitable 
for both ecological and conventional beekeeping, and is also appropriate for use in combination with authorized VMPs.

The use of natural compound product formulations, in some situations of need, offers an alternative strategy for control of varroosis. However, to obtain reliable results, these acaricidal products must be evaluated under temperate climate conditions where the evaporation rate of active ingredients should be stable to achieve good efficacy and to avoid negative impacts on the honeybee colony. The results of this study showed that Hive Clean ${ }^{\circledR}$ was clearly effective, similar to the reports by HOWIS and NOWAKOWSKI (2009), and IMDORF et al. (2003). In contrast, its effectiveness under tropical conditions after treatment of Africanized hybrid bees, presented a limited therapeutical impact of 19.7\% (RODRIGUEZ-DEHAIBES et al., 2017).

The results of this study show that the Hive Clean ${ }^{\circledR}$ formulation has an average efficiency of $91.25 \%$ after split summer treatments. This varroacidal efficiency is higher than previous tests of its main individual components, applied under different field conditions: oxalic acid (TOUFAILIA et al., 2015); formic acid (PIETROPAOLI and FORMATO, 2017), or various essential oils (ALLAM et al., 2003; GOSWAMI et al., 2014). The number of fallen $V$. destructor mites after three Hive Clean ${ }^{\circledR}$ split treatments (Fig. 2) is particularly interesting. This could be the consequence of the treatment time, when colonies in the continental part of Croatia mainly have got pretty much honeybee brood, or due to the fact that the acaricide applied contains a combination of several organic acids, and because of the residual activity of the split treatment. Formic acid is known to be effective against both the phoretic and reproductive phases of $V$. destructor mites (ROSENKRANZ et al., 2010).

In this field study, the acaricidal effect of the food additive Hive Clean ${ }^{\circledR}$ was very similar to the effect observed after the treatment of honeybee colonies with the authorized VMP CheckMite ${ }^{\circledR}$ $(91.96 \%)$. During the winter treatment, Varidol $^{\circledR}$ showed the lowest varroacidal efficacy in experimental group B (Fig. 3), which could be explained by the precedent impact of the Hive Clean ${ }^{\circledR}$ formulation and CheckMite $+{ }^{\circledR}$ treatment.

Hive Clean ${ }^{\circledR}$ as a food additive with acaricidal effect might thus be considered to be an appropriate alternative for varroosis control for organic and conventional apiaries under mild climate conditions. Additionally, it is possible to alternate Hive Clean ${ }^{\circledR}$ with other synthetic acaricides in rotation programmes in order to decelerate the resistance of $V$. destructor mites to pesticides used repeatedly, or to reduce the impact on increasing beeswax contamination. All treatments must be performed in accordance and in combination with other specific regulations ordered by the national authorities.

\section{References}

AKYOL, E., H. YENINAR (2008): Controlling Varroa destructor (Acari: Varroidae) in honeybee Apis mellifera (Hymenoptera: Apidae) colonies by using Thymovar ${ }^{\circledR}$ and BeeVital ${ }^{\circledR}$. Ital. J. Anim. Sci. 7, 2, 237-242.

ALLAM, S. F. M., M. F. HASSAN, M. A. RISK, A. U. ZAKI, B. PAPIEROK (2003): Utilization of essential oils and chemical substances alone or in combination against Varroa mite (Varroa destructor), a parasite of honeybees. Iobc. Wprs. Bull. 26, 273-278. 
I. Tlak Gajger and P. Sušec: Efficacy of varroacidal food additive appliance during summer treatment of honeybee colonies

ANONYMOUS (2008): EMA - European Medicines Agency, EMA/CVMP/EWP/459883/2008, Committee for Medicinal Products for Veterinary Use (CVMP). Guideline on veterinary medicinal products controlling Varroa destructor parasitosis in bees. http://www.ema.europa. eu/docs/en_GB/document_library/Scientific_guideline/2010/11/WC500099137.pdf

ANONYMOUS (2015): Program for varoosis control, Croatian National Regulation on animal protection measures against infectious and parasitic diseases and on related financing.

ANONYMOUS (2018): Program for varoosis control, Croatian National Regulation on animal protection measures against infectious and parasitic diseases and on related financing.

CHEN, Y. P., J. S. PETTIS, J. D. EVANS, M. KRAMER, M. F. FELDLAUFER (2004): Transmission of Kashmir bee virus by the ectoparasitic mite Varroa destructor. Apidologie 35, 441-448.

DELAPLANE, K. S., J. VAN DER STEEN, E. GUZMAN-NOVOA (2013): Standard methods for estimating strength parameters of Apis mellifera colonies. J. Apic. Res. 52, 1-12.

DI PRISCO, G., F. PENNACCHIO, E. CAPRIO, H. F. Jr. BONCRISTIANI, J. D. EVANS, Y. CHEN (2011): Varroa destructor is an effective vector of Israeli acute paralysis virus in the honeybee, Apis mellifera. J. Gen. Virol. 92, 151-155.

DOI: $10.1099 /$ vir.0.023853-0

GOSWAMI, V., P. SRIVASTAVA, M. S. KHAN (2014): Efficacy of essential oils against Varroa destructor infesting Apis mellifera Linn. colonies and their impact on brood development. J. Appl. Nat. Sci. 6, 27-30.

GOULSON, D., E. NICHOLLS, C. BOTÍAS, E. L. ROTHERAY (2015): Bee declines driven by combined stress from parasites, pesticides, and lack of flowers. Science 347, 1255957.

HOWIS, M., P. NOWAKOWSKI (2009): Varroa destructor removal efficiency using Beevital Clean preparation. J. Apic. Sci. 53, 15-20.

IMDORF, A., J. D. CHARRIERE, V. KILCHENMANN, S. BOGDANOV, P. FLURI (2003): Alternative strategy in central Europe for the control of Varroa destructor in honey bee colonies. Apiacta 38, 258-285.

LODESANI, M., C. COSTA, G. SERRA, R. COLOMBO, A. G. SABATINI (2008): Acaricide residues in beewax after conversion to organic beekeeping methods. Apidologie 39, 324-333.

MAGGI, M. D., S. R. RUFFINENGO, P. NEGRI, M. J. EGUARAS (2010): Resistance phenomena to amitraz from populations of the ectoparasitic mite Varroa destructor of Argentina. J. Parasitol. Res. 107, 1189-1192.

MARTIN, S. J., A. C. HiGHFiELD, L. BRETTELl, E. M. VILlalobOS, G. C. BUDGE, M. POWELL, S. NIKAIDO, D. C. SCHROEDER (2012): Global honey bee viral landscape altered by a parasitic mite. Science 336, 1304-1306.

MULLIN, C. A., M. FRAZIER, J. L. FRAZIER, S. ASHCRAFT, R. SIMONDS, J. S. PETTIS (2010): High levels of miticides and agrochemicals in North American apiaries: implications for honey bee health. PLoS One 5, e9754.

NAZZI, F., S. P. BROWN, D. ANNOSCIA, F. DEL PICCOLO, G. DI PRISCO, P. VARRICCHIO, G. DELLA VEDOVA, F. CATTONARO, E. CAPRIO, F. PENNACCHIO (2012): Synergistic 
I. Tlak Gajger and P. Sušec: Efficacy of varroacidal food additive appliance during summer treatment of honeybee colonies

parasite-pathogen interactions mediated by host immunity can drive the collapse of honey bee colonies. PLoS Pathogens 8, 6, e1002735.

NAZZI, F., Y. LE CONTE (2016): Ecology of Varroa destructor, the Major Ectoparasite of the Western Honey Bee, Apis mellifera. Ann. Rev. Entomol. 61, 417-432.

PIETROPAOLI, M., G. FORMATO (2017): Liquid formic acid 60\% to control varroa mites (Varroa destructor) in honey bee colonies (Apis mellifera): protocol evaluation. J. Apic. Res. DOI: 10.1080/00218839.2017.1376767.

RAMSEY, S. D., R. OCHOA, G. BAUCHAN, C. GULBRONSON, J. MOWERY, A. COHEN, D. LIM, J. JOKLIK, J. M. CICERO, J. D. ELLIS, D. HAWTHORNE, D. VAN ENGELSDORP (2018): Varroa destructor feeds primarily on honey bee fat body tissue not haemolymph. In: Abstract Book EurBee 8. (De Graaf, D. C., R. J. Paxton, Eds.), $8^{\text {th }}$ Congress of Apidology, 18-20 September 2018, Ghent, Belgium, pp. 140-141.

RUFFINENGO, S. R., M. D. MAGGI, S. FUSELLI, F. G. DE PIANO, P. NEGRI, C. BRASESCO, A. SATTA, I. FLORIS, M. J. EGUARAS (2014): Bioactivity of microencapsulated essentials oils and perspectives of their use in the control of Varroa destructor. Bull. Insect. 67, 81-86.

RODRIGUEZ-DEHAIBES, S. R., V. T. PARIDO SEDAS, G. LUNA-OLIVARS, J. A. VILLANUVA-JIMENEZ (2017): Two commercial formulations of natural compounds for Varroa destructor (Acari: Varroidae) control on Africanized bees under tropical climatic conditions. J. Apic. Res. 56, 58-62.

DOI: $10.1080 / 00218839.2016 .1268323$

ROSENKRANZ, P., P. AUMEIER, B. ZIEGELMANN (2010): Biology and control of Varroa destructor. J. Invertebr. Pathol. 103, S96-S119.

RYABOV, E. V., G. R. WOOD, J. M. FANNON, J. D. MOORE, J. C. BULL, D. CHANDLER, A. MEAD, N. BURROUGHS, D. J. EVANS (2014): A Virulent Strain of Deformed Wing Virus (DWV) of Honeybees (Apis mellifera) Prevails after Varroa destructor-Mediated, or In Vitro, Transmission. PLoS Pathogens 10, 6, e1004230.

DOI: 10.1371/journal.ppat.1004230.

SAMMATARO, D., P. UNTALAN, F. GUERRERO, J. FINLEY (2005): The resistance of varroa mites (Acari: Varroidae) to acaricides and the presence of esterase. Int. J. Acarol. 31, 67-74.

STANIMIROVIĆ, Z., U. GLAVINIĆ, N. LAKIĆ, D. RADOVIĆ, M. RISTANIĆ, E. TARIĆ, J. STEVANOVIĆ (2017): Efficacy of plant-derived formulation "Argus Ras" in Varroa destructor control. Acta Vet. Beograd 67, 191-200.

TLAK GAJGER, I., Z. TOMLJANOVIĆ, LJ. STANISAVLJEVIĆ (2013): An environmentally friendly approach to the control of Varooa destructor mite and Nosema ceranae disease in Carnolian honeybee (Apis mellifera carnica) colonies. Arch. Biol. Sci. 65, 1585-1592.

TOUFAILIA, H. A. L., L. SCANDIAN, F. L. W. RATNIEKS (2015): Towards integrated control of varroa: 2) comparing application methods and doses of oxalic acid on the mortality of phoretic Varroa destructor mites and their honey bee hosts. J. Apic. Res. 54, 1-13. 
I. Tlak Gajger and P. Sušec: Efficacy of varroacidal food additive appliance during summer treatment of honeybee colonies

YANG, X., D. L. COX-FOSTER (2005): Impact of an ectoparasite on the immunity and pathology of an invertebrate: evidence for host immunosuppression and viral amplification. P. Natl. Acad. Sci. USA 102, 7470-7475.

ZIEGELMANN, B., P. ROSENKRANZ, J. D. ELLIS (2013): Standard methods for varroa research. In: The Coloss Beebook, VOL. II: Standard methods for Apis mellifera pest and pathogen research. (Dietemann, V., J. D. Ellis, P. Neumann, Eds.), J. Apic. Res. 52, I.

DOI: 10.3896/ibra.I.52.I.

Received: 31 July 2018

Accepted: 25 October 2018

\section{TLAK GAJGER, I., P. SUŠEC: Varooacidna učinkovitost primjene dodatka hrani tijekom ljetnog tretmana zajednica medonosne pčele (Apis mellifera). Vet. arhiv 89, 87-96, 2019.}

\section{SAŽETAK}

Cilj ovog istraživanja bio je utvrditi učinkovitost Hive Clean ${ }^{\circledR}$ proizvoda tijekom ljetnog tretmana zajednica medonosne pčele (Apis mellifera) protiv varooze, u poljskim uvjetima. Učinkovitost tretmana je utvrđena brojenjem otpalih grinja Varroa destructor nakon višekatne uporabe Hive Clean ${ }^{\circledR}$ proizvoda prema uputama proizvođača, kao i nakon kombinirane uzastopne primjene dva varooacida s različitim aktivnim tvarima. Nakon provedenog tretmana s Hive Clean ${ }^{\circledR}$ proizvodom prosječna učinkovitost pada grinja iznosila je $91,51 \%(89,25$ $93,26 \%$ ). Ukupan broj otpalih grinja je u svim tretiranim zajednicama medonosne pčele bio značajno veći u odnosu na prirodni pad grinja utvrđen tijekom razdoblja prije tretmana. Sukladno dobivenim rezultatima provedenog istraživanja učinkovitosti Hive Clean ${ }^{\circledR}$ proizvoda, kao dodatka hrani s akaricidnim učinkom, može ga se smatrati prikladnim za kontroliranje varooze. Također, prihvatljiv je za uporabu u kombinaciji s odobrenom veterinarsko medicinskim proizvodima za kontroliranje varooze, i to u pčelinjacima s ekološkim i konvencionalnim načinom pčelarenja.

Ključne riječi: Apis mellifera; Varroa destructor; Hive Clean ${ }^{\circledR}$; varooacidna učinkovitost 